\title{
REVIEW
}

OPEN ACCESS

\section{Foreign Direct Investment (FDI) in India's Retail Sector}

Dr Hiranya K Nath ${ }^{\dagger}$

\begin{abstract}
This article presents an overview of retail trade in India in the wake of the country's new policy that will allow foreign capital in multi-band retailing. It discusses various potential benefits and costs of foreign direct investment (FDI) in the retail sector, particularly in terms of its effects on traditional retailers, employment, consumers, farmers, and local manufacturers. It argues that given somewhat slower growth projection for the Indian economy during the next decade, various structural issues including inadequate infrastructure and a lack of affordable real estate, and the prevalent structure of the agricultural markets, it is unlikely that all the potential benefits and costs will be realised to their fullest extent, at least in the foreseeable future. The economic dynamics and the political process will play an important role in determining the outcomes of this move to allow FDI in the retail sector and will ultimately determine the effects on various stakeholders.
\end{abstract}

Keywords: Foreign direct investment (FDI), multi-brand retailing, supply chain, logistics

\footnotetext{
${ }^{\dagger}$ Associate Professor of Economics, Sam Houston State University, Huntsville, Texas (USA), TX 77341-2118; E-mail: eco_hkn@shsu.edu; Phone: +1-936-294-4760

(C) 2013 Nath. This is an Open Access article distributed under the terms of the Creative Commons Attribution License (http://creativecommons.org/licenses/by/2.0), which permits unrestricted use, distribution, and reproduction in any medium, provided the original work is properly cited.
} 
Nath. Space and Culture, India 2013, 1:1

http://www.spaceandculture.in/index.php/spaceandculture/article/view/17/7

Page 3

\section{Introduction}

In December 2012, Indian Parliament approved of the central government's decision to allow foreign direct investment (FDI) in multi-brand retailing. This paved the way for foreign retailers to open retail stores with 51 per cent ownership in major cities to sell a large variety of products under one roof. ${ }^{1}$ However, the state governments will have the rights to prevent foreign retailers from opening up stores in their respective states. It may be noted that foreign capital has already been allowed in single-brand retailing. Furthermore, there are several indirect channels, such as franchise agreements, cash and carry wholesale agreements, strategic licensing agreements, manufacturing and wholly owned subsidiaries, through which foreign companies including large retailers have already had access to the Indian market. ${ }^{2}$ Nevertheless, the debate over FDI in retailing has been going on for quite some time. The opposition to foreign capital in this sector has in fact delayed the passing of this bill. There have been many speculations on its potential benefits and costs and, depending on their socio-political-economic ideologies; the commentators have positioned themselves either in favour or against this policy.

However, it has been very difficult to conduct an objective assessment of potential benefits and costs of FDI in retailing for several reasons. First, since retailing in India has been taking place predominantly in the unorganised sector, there are no reliable data. Most studies and reports that have been published rely on estimates based on strong assumptions. Second, although there have been cases of FDI in retail sector in other developing countries of Southeast Asia and Latin America and we can learn from their

\footnotetext{
${ }^{1}$ For now, the foreign retailers will be allowed only in cities with population of more than one million.

${ }^{2}$ For example, German retailer Metro AG entered India through cash and carry wholesale trading channel. WalMart has entered India as a joint venture with Indian firm Bharati Enterprises. See Gupta (2012) for examples of other channels.
}

experiences, there have been wide variations in their experiments and outcomes and, for some countries, not much time has elapsed since they allowed foreign capital in retailing. Third, retailing is a service the provision of which depends on a number of noneconomic factors that are difficult to factor in an objective assessment of the potential benefits and costs. In particular, the dynamism in the markets that is defined by consumer tastes and preferences (which constantly change particularly when the economy grows at a rapid pace) is hard to fathom.

The primary objective of this article is to provide an overview of retailing in India and a discussion of potential benefits and costs of FDI in the context of the new law that provides access of foreign capital into this sector. The rest of the article is organised as follows. In the next section, I discuss the economics of retailing. It covers the concept of retailing as a service and its place in the supply chain. Following this, it presents a brief discussion on India's retail sector highlighting its special features that need to be considered in a comprehensive assessment of the potential effects of FDI in this sector. Then I discuss the potential benefits and costs. I also consider some realistic issues that are important in realising these benefits and costs. The final section includes the concluding remarks.

\section{What is Retailing?}

According to a definition attributed to Philip Kotler, retailing includes all the activities involved in selling goods or services directly to the final consumers for personal, non-business use. ${ }^{3}$ Although, selling goods or services directly to the final consumers is the primary activity in retailing, there are a number of auxiliary activities that are associated with it. As Figure 1 illustrates, retailers are involved in the distribution phase of an integrated supply chain

\footnotetext{
3 In 2004, Delhi High Court defined the term 'retail' as a sale for final consumption in contrast to a sale for further sale or processing.
} 
Nath. Space and Culture, India 2013, 1:1

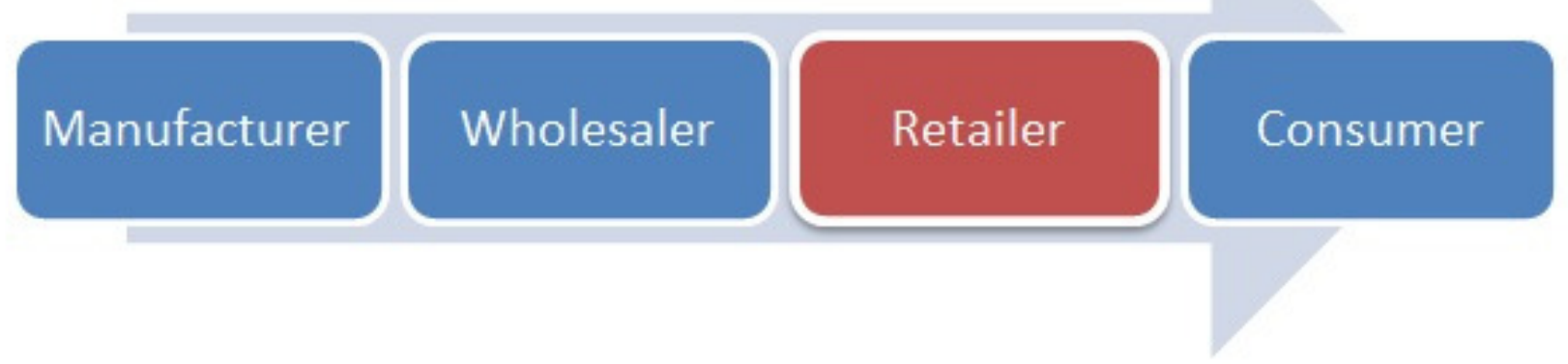

Figure 1: A simple supply chain

and are in direct interface with consumers. ${ }^{4}$ At the front-end, retailers directly sell goods or services to consumers. However, at the backend, they are involved in procuring (also called sourcing), storing, and transporting products that they retail. In many cases, they are involved in processing and packaging as well. The logistics of retailing primarily depends on transportation, communication, and storage infrastructure. ${ }^{5}$ Well-developed infrastructure helps improve logistics and leads to efficiency gain in retailing.

Over time, retailing has been organised in many different ways and, as a result, one can see several different formats of retail trading. One such format that is relevant for the topic is multibrand (multi-product) retailing. In case of multibrand retailing, the retailer offers a wide range of products that are produced by diverse producers presumably in geographically dispersed locations. Thus, by providing a vital link between a large number of producers and a large number of consumers, this format of retailing could potentially generate several benefits to the two sides of the market. However, the logistics for multi-brand or multi-product retailing could be quite complicated.

\footnotetext{
${ }^{4}$ However, a supply chain could be much more complicated than the one illustrated by the figure.

${ }^{5}$ The dictionary meaning of logistics is "the handling of the details of an operation" (Merriam-Webster).
}

In each stage of this supply chain, value is added and the total value addition determines the price of the product paid by the customer. At the retail stage, the value addition depends on the cost of retail logistics that, as indicated above, depends on transportation, communication, and storage infrastructure, and the profit margin for undertaking the retail enterprise. Any efficiency gain in retail logistics may benefit consumers in terms of lower prices and better quality of products and customer service.

\section{The Retail Sector in India}

In India, retailing has been an important service industry. In particular, with faster growth of the overall economy, higher disposable incomes, and rapid urbanisation in recent years, there has been acceleration in the growth of this sector. In fact, it has been identified as a sunrise industry with enormous future growth potential.

\section{The Evolution of India's Retail Sector}

From figure (2), one can discern four stages in the evolution of retailing in India. Historically, the seed of retailing germinated in village fairs or melas that were primarily a source of entertainment rather than an outlet for a wellconceived economic activity. Later on, as the consumption basket expanded and production for market took hold, some forms of retailing started shaping up and they evolved into the traditional neighborhood shops (kiranas, 
convenience stores etc.). In rural areas, these kirana shop-owners had tremendous market power and as such, the consumers had to face the wrath of a number of unfair practices. A lack of proper distribution network in an economy with geographically dispersed production locations aided the profiteering activities of these retail shops. Thus, the government stepped in

\section{Evolution of Indian Retail}
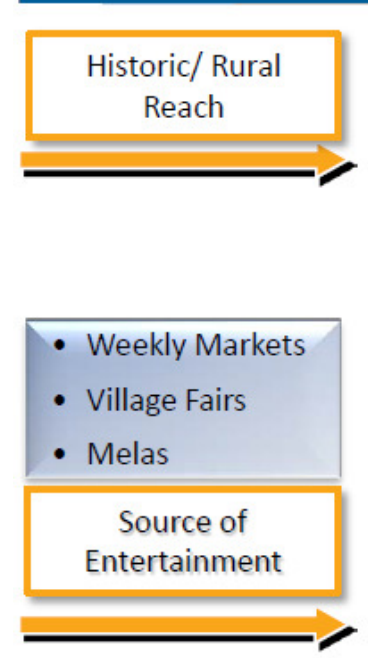
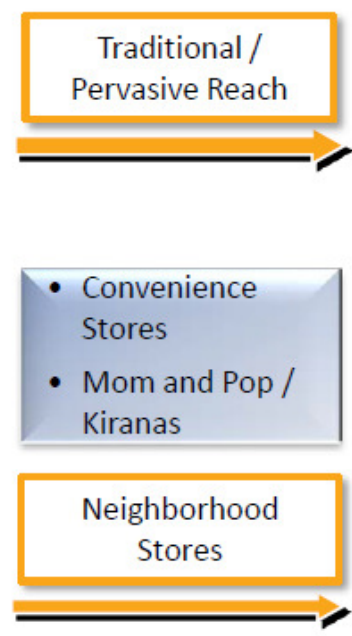

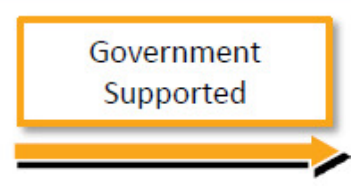

- PDS Outlets

- Khadi Stores

- Cooperatives

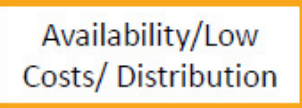

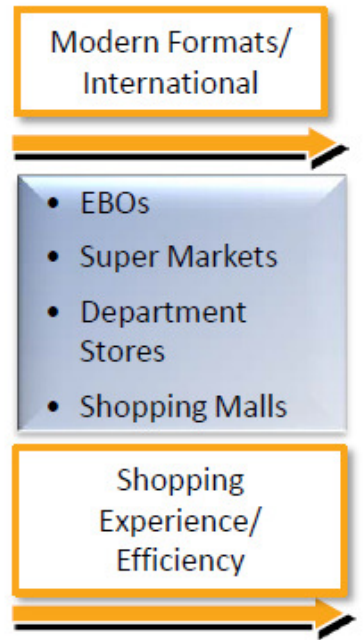

Figure 2: The evolution of India's retail sector

Note: Reproduced from a 2011 resurgent India research report entitled "Indian Retail Sector" available for download from http://www.resurgentindia.com/Research/researchreports.aspx; downloaded on March 27, 2013)

with the objective of ensuring distribution of basic items at fair prices and established the public distribution system (PDS). The government also supported Khadi stores and cooperatives that essentially helped small producers involved in various traditional production activities. The government intervention helped remove some of the major distributional bottlenecks and that in turn ensured availability and fair price. However, bureaucratic red-tapism, corruption, and perverse incentives ingrained in even well intentioned public policies made the outcomes less than optimal.

The economic reforms and liberalisation in the 1990s facilitated the entry of foreign brands. With the rise in disposable income and the growth of urban middle class, the household consumption basket expanded to include items that Indian consumers did not typically purchase until then. The entry of foreign goods contributed to this trend and expanded consumers' choice set. These developments created an environment conducive to the introduction of modern retailing that includes exclusive brand outlets (EBOs), super markets, departmental stores, and shopping malls. Almost all major Indian private corporate groups (The Tatas, The Reliance, The Birlas) have now entered the retail sector.

Although, the evolution of India's retail sector has seen the ushering in of modern formats of retailing, all other formats that can be seen in the earlier stages of this process coexist. In fact, the potential changes in the relative balance of power among these various formats and their direct beneficiaries in the advent of large foreign retailers are at the core of the ongoing debate.

\section{The Size and Structure of the Indian Retail Sector} It is very difficult to know the true size of the retail sector in India primarily due to the unorganised nature of the sector. As shown in Table 1, the total merchandise consumption in 2012 is estimated to be USD 490 billion. Since it 
Nath. Space and Culture, India 2013, 1:1

represents the value of all goods that are presumably delivered to the consumers by the retailers it gives a rough estimate of the retail sales in India. Thus, it accounts for about $25 \%$ of GDP (Gross Domestic Product). However, the value addition due to retailing and therefore the contribution of the retail sector to GDP would be much smaller. ${ }^{6}$ As one can see, more than $90 \%$ of these sales take place in the unorganised retail sector. However, the share of the organised retail has increased from about 4\% in 2001 to more than $7 \%$ in 2012 . That is, the organised retail sector has been growing faster than the unorganised sector. The unorganised retail sector has employed about 22 million workers in 2012 and it has increased from 18 million in 2001. In contrast, the organised retail employs less than a million workers. Overall, the retail sector is the second largest employer after agriculture in India. ${ }^{7}$

\section{Distinctive Characteristics of India's Retail Sector}

Several important characteristics of India's retail industry need to be considered while assessing the potential effects of FDI in retailing. First, it is dominated by unorganised retailing. As discussed above, the unorganised retail sector consists of the traditional formats of retailing such as the local kirana shops, owner operated general stores, paan-beedi shops, convenience stores, handcart and pavement vendors, weekly haats, and bazaars. In contrast, the organised retail sector includes licenced retailers who are registered for sales tax, income tax etc. The privately owned large retail businesses and the corporate-backed retail chains and hypermarkets constitute this organised retail industry in India. It is apparent from Table 1 (alongside other estimates) that, unorganised retailing accounts for more than $90 \%$ of all retail trade in India.

\footnotetext{
${ }^{6}$ According to AT Kearney (2012), the overall retail market contributes $14 \%$ of India's GDP.

${ }^{7}$ According to Patibandla (2012), the retail sector accounts for $8 \%$ of total employment.
}

Table 1: Size of the retail industry in terms value and employment in India

\begin{tabular}{|l|c|c|}
\hline & 2001 & 2012 \\
\hline $\begin{array}{l}\text { Estimated merchandise } \\
\text { consumption (retail sales) (billions } \\
\text { of USD) }\end{array}$ & 450 & 1958 \\
\hline - Unorganised retail sector & $\begin{array}{c}115 \\
(95.8 \%)\end{array}$ & $\begin{array}{c}455 \\
(92.9 \%)\end{array}$ \\
\hline Organised retail sector & $5(4.2 \%)$ & $\begin{array}{c}34 \\
(7.1 \%)\end{array}$ \\
\hline $\begin{array}{l}\text { No. of direct employees in the } \\
\text { unorganised retail sector (millions) }\end{array}$ & 18 & 22 \\
\hline $\begin{array}{l}\text { No. of employees in the organised } \\
\text { retail sector (millions) }\end{array}$ & 0.1 & 0.7 \\
\hline
\end{tabular}

Source: Adapted from Technopak Analysis

Second, the retail industry in India is highly fragmented with millions of very tiny outlets scattered all over the country. According to Guruswamy et al. (2005), there were about 11 million outlets and only $4 \%$ of them were larger than 500 square feet in size. Patibandla (2012) estimates the number of the kirana stores to be around 12 million spread across 5,000 towns and 600,000 villages throughout the country. The proliferation of retail outlets is primarily explained by the relative ease with which a retail outlet can be established. The traditional forms of retailing require low investment and minimal infrastructure. For the same reason retailing has also been the primary form of disguised unemployment or underemployment in India. Most retail outlets are family-owned with family members working part-time or full-time, thus making it harder to obtain a precise estimate of actual employment generated by the retail sector in India.

Third, food retail trade is the largest segment of the retail industry in India. According to Guruswamy et al. (2005), it accounts for $63 \%$ of total retail sales. At the family level, consumer expenditure on food accounts for, on an average, $50 \%$ of the total retail purchase. ${ }^{8}$ However, the

\footnotetext{
${ }^{8}$ See Patibandla (2012).
} 
Nath. Space and Culture, India 2013, 1:1

http://www.spaceandculture.in/index.php/spaceandculture/article/view/17/7

Page 7

share of food would be much larger for lowincome groups. While kirana stores sell food grains and dry foods, pavement stalls and sometimes better-organised larger vendors sell fruits and vegetables. Primarily due to a lack of proper infrastructure, about $40 \%$ of vegetables and fruits are destroyed before they come to the market. At the procurement stage, hygienic practices are often ignored.

Fourth, the informal nature of the relationship between the traditional retail stores and the consumers is also an important feature of India's retail sector. The repeated interactions with customers who live in geographically proximate locations generate mutually beneficial trust in exchanges. The customers are often able to obtain their consumables on credit and the stores earn customer loyalty.

Finally, the potential for growth of India's retail sector is enormous. During the last two decades, the middle class has grown significantly and its average income has increased and its consumer aspirations. With the improvement in transportation and communication infrastructure, there has been a convergence of consumer tastes. Furthermore, India has a relatively young population. The median age is about 26 years. That is, more than 600 million people are under the age of 26 years. They are not only a source of very large future demand but also their tastes and preferences are likely to be less rigid and therefore, more amenable to the changing composition of consumer products. According to a report published by The Boston Consulting Group (2012), India's consumer market is expected to grow 3.6 times from an estimated USD 991 billion in 2010 to an estimated USD 3,584 billion in $2020 .^{9}$ As the report discusses, rising household income, urbanisation, the shift away from the traditional joint-family structure, and the coming of age of

\footnotetext{
${ }^{9}$ Note that the estimate presented in Table 1 is of spending on merchandise consumption that is a part of overall consumer spending.
}

"Gen I" will all contribute to this growth. ${ }^{10}$ Among the seven different categories of consumer spending, housing and consumer durables, education and leisure, and others (that include personal care, baby care, loan payment, holidays, and social gatherings) are poised to grow the fastest.

\section{Potential Benefits and Costs of FDI in India's Retail Sector}

In this section, I will briefly discuss some of the potential benefits and costs of FDI in India's retail sector. ${ }^{11}$ In general, FDI helps build the stock of physical capital in the sector in which such investment takes place. In developing countries where the stock of physical capital is low and there is a shortage of domestic funds to finance investment, FDI may go a long way in augmenting the physical capital stock and increasing productivity. The potential benefits and costs of FDI in retailing have also been construed as arguments respectively in favour and against FDI in the retail sector. I will also discuss some of the real issues that are important in realising the benefits and costs.

\section{Potential Benefits}

\section{Infusion of Capital}

As discussed above, retailing depends on supply chain logistics. An efficient logistics - based on well-developed networks of transportation, communication, and storage infrastructure - not only provides timely and uninterrupted market access to the producers but also ensures quality and lower prices to the consumers. For example, without the development of appropriate storage infrastructure, the farmers cannot have an access to an efficient market system that pays fair prices and have to fall prey to unscrupulous

\footnotetext{
10 The report defines "Gen I" as the generation of consumers who have "grown up in an era of economic liberalization and social freedom...."I" stands for India, independence, and individuality" (BCG 2012, pp. 3)

${ }^{11}$ Durand (2007) presents a diagrammatic representation of some of the potential positive as well as negative externalities from FDI in the retailing sector of a developing country.
} 
middlemen. These middlemen pay lower prices to the farmers and charge higher prices to the retailers. Furthermore, since a significant portion of the produces are destroyed in the process of being transported from the farmers to the retailers and ultimately to the consumers, the consumers have to pay higher prices for relatively low quality products. In India, primarily due to the unorganised and fragmented nature of the retail sector, there is a severe shortage of funds for investment in the basic infrastructure required mainly for back-end retail logistics. The retailers are too small to make such large investments. Although government has stepped in, the infrastructure built by the government has not been adequate. Allowing FDI in retailing is expected to go a long way in alleviating this situation because the large retailers would build the necessary infrastructure to create an integrated back-end supply chain for efficiency.

\section{Technology Transfer}

In addition to augmenting physical capital stock, FDI in developing countries also acts as a conduit of technology transfer. Foreign capital brings along advanced technology from developed countries that increases productivity. In retailing, advanced technologies will tremendously improve processing, grading, handling and packaging of goods. The use of cold-storage facilities, refrigerated vans, pre-cooling chambers will reduce wastage and help maintain product quality. Electronic weighing, billing, and barcode scanning will add to accuracy and efficiency. These efficiency gains will lower price and improve quality for the consumers.

\section{Higher Consumer Wellbeing}

The entry of foreign retailers will provide the customers, particularly in the organised retail sector, with the opportunity to choose from a wide variety of brands and products. More choice improves consumer wellbeing. In addition, larger space for product display, hygienic environment in the shopping area, availability of a large number of products under one roof, and better customer care will increase customer satisfaction. As some studies show, shopping in large malls and departments also provides entertainment to the customers. ${ }^{12}$

\section{Competition and Inflation Control}

The advent of multinational retailers will increase competition that will benefit consumers. There will be special offers and various free or discounted services that will accompany the products. This competition will also keep prices low that in turn will be a check on inflation. As discussed above, lower prices are expected because of more efficient supply chain logistics that reduces the cost of moving goods from the producers or wholesalers to the retailers and ultimately to consumers. The development of transportation and storage infrastructure also helps reduce volatility of prices, particularly of agricultural products.

\section{Benefits to the Farmers, Local Suppliers, and Domestic Manufacturers}

Supporters of FDI in the retail sectors argue that the farmers will benefit immensely from the entry of multinational retailers. Primarily through an extensive backward integration and superior technical and operational expertise, these retailers will be able to provide stability and economies of scale. The construction of storage facilities and improved transportation will reduce the losses to the farmers due to easily perishable nature of their products and will provide a larger market. The farmers will receive better/fair prices by directly selling to organised retailers. They will be able to get away from excessive reliability on intermediaries who often pay lower prices. Furthermore, local suppliers and domestic manufacturers will gain access to larger, and potentially to global markets as the multinational retailers will establish extensive forward and backward linkages that will spread beyond national boundaries. ${ }^{13}$

\footnotetext{
${ }^{12}$ See, for example, Mukherjee et al. (2012)

${ }^{13}$ See Coe and Hess (2005) for a discussion on how FDI in retail leads to rapid and dramatic consolidation in the
} 
Nath. Space and Culture, India 2013, 1:1

http://www.spaceandculture.in/index.php/spaceandculture/article/view/17/7

Page 9

\section{Employment Generation}

The growth of the organised retail sector because of FDI is expected to create jobs not only in frontend retailing but also in related activities at the back-end of retailing. ${ }^{14}$ Since these jobs will be in the organised sector, the laws that protect the interests of the workers will be applicable to the retail sector. This will ensure the quality of jobs offered in the organised retail sector. Higher wages and better work conditions will improve the standard of living for those who find employment in the organised retail sector.

\section{Government Revenue Generation}

Since most retail outlets in India are in the unorganised sector, they hardly pay any taxes to the government. There are tax leakages via under-invoicing or non-reporting of sales. As FDI in the retail sector helps the organised sector grow, it will generate revenue for the government. According to an estimate, the tax revenue due to the projected growth of the organised retail is expected to be USD 16.2 billion. ${ }^{15}$

\section{Potential Costs}

\section{Displacement of Unorganised Small Retailers}

Those who oppose FDI in India's retail sector argue that foreign capital in this sector will facilitate rapid growth of organised retailing in India that will adversely affect millions of small retailers in the unorganised sector. They will go out of business. ${ }^{16}$ Because of their large scale, the organised retailers will wield their market power and eventually come to dominate retailing. They will resort to predatory pricing as they can withstand losses for a longer duration in

distribution, wholesale and manufacturing/agricultural production sectors of host economies.

${ }^{14}$ The employment effect of the entry of large foreign retailers would vary over time. For a detailed analysis of employment effects on Walmart, see Basker (2005).

${ }^{15}$ Technopak (2012)

${ }^{16}$ As Coe and Hess (2005) argue, "local independent stores, department stores and fresh markets have been adversely affected by loss of market share to foreign-owned or controlled supermarkets and hypermarkets". the beginning but once they become dominant in the market they will charge higher prices to the customers, which will also adversely affect customer welfare.

\section{Loss of Employment}

As discussed above, the retail sector is a major source of employment for millions of people in India. Family members run most retail stores in the unorganised sector. Since labour productivity will be higher in the organised retail sector, although it will create some jobs, there will be far less jobs than those that will be replaced. FDI could cause dislocation to the existing traditional supply chain and that in turn will cause even more job losses.

\section{Competition for Domestic Retailers}

Domestic retailing in the organised sector is still in its infancy. The advent of foreign retailing giants is likely to give fierce competition to the domestic retailers who may be eventually acquired by the foreign retailers. The competition is not only in terms of product prices but also in terms of product varieties and their quality. Due to their extensive sourcing networks, the multinational retailers will be able to offer better quality goods produced in different countries where the domestic retailers may not have access.

\section{Loss of Markets for the Farmers, Local Suppliers, and Domestic Manufacturers}

The foreign retailers may not necessarily source their supplies from the local farmers, suppliers, and domestic manufacturers. Small farmers may face serious problems such as rejection of supplies because of non-compliance with quality standards, difficulties in disposing rejected quantities, inconvenient delivery schedules, and unwillingness on the part of the big retailers to extend production and consumption loans to farmers. In such cases, the farmers and domestic manufacturers will lose their markets. ${ }^{17}$

\footnotetext{
${ }^{17}$ See Sarma (2005) for a discussion.
} 
Nath. Space and Culture, India 2013, 1:1

http://www.spaceandculture.in/index.php/spaceandculture/article/view/17/7

\section{Increase in Real Estate Costs}

The foreign retailers will look for space in and around city centers to open their stores and malls. In many large cities, there has already been a shortage of spaces particularly in prime locations. Thus, the entry of the foreign retailers will increase the price of real estate manifold in those cities, adversely affecting smaller businesses.

\section{Some Real Issues}

On both sides of the debate over FDI in India's retail sector, these arguments (potential benefits and costs) have some merits. However, one must be realistic in evaluating these benefits and costs. Several important issues need to be considered in order to determine whether the gains and losses that have been discussed above would be realised fully in India.

First, even with the most optimistic growth projection, the organised sector will not be the dominant player in India's retail trade in near future. According to an estimate published by Technopak (2012), the organised retail will grow to no more than $20 \%$ of the total merchandise retail trade by 2021 . The report points out that the growth of this sector would be constrained by the potential slowdown of India's economic growth and structural issues such as a lack of affordable real estate, sourcing and distribution. Furthermore, the fact that FDI will be allowed in cities with population of more than one million and several states will not allow the foreign retailers will also restrict growth. Only 53 cities in India have an excess of more than one million people. Even if they are allowed everywhere, the size of the markets (in terms of total sales) may not be profitable for big retailers in rural areas and small towns. In addition, because of the informal nature of the relationship between consumers and traditional retail stores that often work to the consumers' advantage, they may not be willing to switch to large retail stores for their daily purchasing needs. ${ }^{18}$

Second, the impact on employment is not clear. As the overall retail sector grows (along with the economy), there will be growth in employment, particularly in the unorganised sector which will remain predominant in retail trade. In addition, as the organised sector grows, there will be new jobs in that sector but because of the relatively small size; these jobs will not have any significant impact on overall employment. There is likely to be some job losses in unorganised retailing due to the growth of the organised retail sector but these losses will be confined to urban centres with large shopping malls and departmental stores. ${ }^{19}$

Third, the growth of organised retail due to FDI is expected to lower price and be an instrument of taming inflation. This expectation is based on the assumption that through building back-end infrastructure and the large scale of operations, the big retailers will reduce the cost of distributing merchandise and will pass on this gain to the consumers in terms of lower prices. However, several constraints will prevent these benefits from being realised at least in the near future. As these retailers invest in back-end retail infrastructure, the efficiency gain from such

\footnotetext{
${ }^{18}$ Some of the advantages include proximity, purchase on credit, and bargaining. See Mukherjee et al. (2011)

19 So far, India's experience with organised retailing, particularly with large malls and departmental stores, has been very limited to conduct rigorous study to derive definitive conclusions. A small sample survey of small shops and hawkers within about one-kilometre radius of a shopping mall in Greater Mumbai indicates that there has been "a decline in sales of groceries, fruits and vegetables, processed foods, garments, shoes, electronic and electrical goods in these retail outlets, ultimately threatening 50 per cent of them with closure or a major decline in business" (Kalhan, 2007). This means job losses in the unorganised sector. However, this decline may not be entirely attributed to the establishment of the mall. This is because there have been other changes in that area, such as closure of mills and opening of corporate offices that changed the composition of consumers with different shopping preferences (Kalhan, 2007).
} 
Nath. Space and Culture, India 2013, 1:1

http://www.spaceandculture.in/index.php/spaceandculture/article/view/17/7

investment will also depend on overall transportation (and communication) infrastructure of the country that will complement their investment efforts. Although, there have been some improvements during the last decade or so, the overall infrastructure is still far behind the level that will make the country competitive. Furthermore, as discussed above, food is the largest segment of retailing in India. While large organised retailers have experienced significant growth in their share in the sales of non-food items such as apparel, jewellery \& watches, electronics, home improvement, pharmacy, footwear etc., their share and growth in food retailing has been relatively small. In fact, the share has been projected to grow from about $3 \%$ in 2012 to about 5\% in $2021 .^{20}$ This small share can partially be explained by consumers' preference for non-branded products when it comes to food items that are primarily sold by traditional retailers. ${ }^{21}$ Furthermore, it has been argued that the market structure prevalent in India will not allow the retailers to integrate their food supply chain. "The lack of direct access to farmers for sourcing, interstate movement of goods, tax structures, and inadequate capacities in the food supply chain will act as the chief barriers to this integration" (Technopak, 2012, pp. 6). Since food prices contribute significantly to the overall inflation, this inability on the part of large retailers to grow their share in food retailing will fail their role in providing stability to inflation. For the same reason, the farmers are also unlikely to benefit from the growth of organised retailing.

Finally, FDI has been permitted in the retail sector in many other emerging market economies and there have been diverse experiences. Since India is often mentioned in the same breath as China because of its large population, economic growth, and the potential

\footnotetext{
${ }^{20}$ Technopak (2012)

${ }^{21}$ Mukherjee et al (2011) provide evidence of such consumer preference.
}

as an economic superpower, let us briefly examine China's experience since it opened up its retail sector to FDI in $1992 .{ }^{22}$ Although, foreign ownership was initially restricted to 49 per cent, those restrictions were gradually lifted and, after China's accession to World Trade Organization (WTO) in 2004, were completely removed. The retail sector has registered significant growth in China during this period. Between 1996 and 2001, over 600 hypermarkets were opened in China. ${ }^{23}$ The number of traditional small retail outlets (similar to kiranas) increased from 1.9 million to over 2.5 million during the same period. Employment in the retail and wholesale trade increased from about $4 \%$ of the labour force in 1992 to about 7\% in 2001. Thus, FDI does not seem to have caused a decline of the traditional retailing and a fall in employment in China. Of course, the rapid economic growth of China over last two decades has fuelled an unprecedented increase in consumption spending and consequent growth of the retail sector.

Overall, the discussion suggests that it is unlikely that the unorganised retail sector will be swept away by the advent of foreign capital in multibrand retailing in India. In addition, some of the potential benefits emphasised by the supporters of FDI will not be realised to their fullest in near future.

\section{Concluding Remarks}

This article gives an overview of retail trade in India. It discusses various potential benefits and costs of FDI in the retail sector in the wake of the government move to allow foreign capital in multi-brand retailing. It argues that given the slower growth projection for the Indian economy during the next decade, various structural issues including inadequate infrastructure and a lack of

\footnotetext{
22 Bhattacharyya (2012) presents some case studies from India to highlight the effects of foreign capital on various stakeholders.

${ }^{23}$ These numbers are obtained from the discussion paper circulated by the Department of Industrial Policy and Promotion (2010).
} 
Nath. Space and Culture, India 2013, 1:1

http://www.spaceandculture.in/index.php/spaceandculture/article/view/17/7

Page 12

affordable real estate, and the prevalent structure of the agricultural markets, it is unlikely that all the potential benefits and costs will be realised to their fullest extent, at least in the foreseeable future. The economic dynamics and the political process will play an important role in determining the outcomes of this move to allow FDI in the retail sector and will ultimately determine the effects on various stakeholders.

\section{Acknowledgement}

The author would like to thank an anonymous reviewer and the editor for useful comments. The usual disclaimer applies.

\section{About the author}

Hiranya K. Nath is also currently a partner at the Business Information Technologies (BIT) Global Research Network at UCLA Anderson School of Management, Los Angeles (USA), and has been a Visiting Fellow at Queensland University of Technology, Brisbane, Australia. Dr. Nath's research interests include inflation and relative price behavior, information economy, and various issues related to developing and transition economies. He has published in reputed refereed journals like Applied Economics, Applied Economics Letters, Applied Financial Economics Letters, California Management Review, Comparative Economic Studies, Economics Letters, Emerging Markets Finance and Trade, Journal of International Trade \& Economic Development, Journal of Macroeconomics, Journal of Money, Credit and Banking, and Review of Development Economics. He earned his Ph.D. in Economics from Southern Methodist University, Dallas (USA).

\section{References}

AT Kearney (2012). Global Retail Expansion: Keeps On Moving. New York: A. T. Kearney LLC.

Basker, E. (2005). Job Creation or Destruction? Labor Market Effects of Wal-Mart Expansion, Review of Economics and Statistics, 87(1), pp. 174-183

Bhattacharyya, R. (2012). The Opportunities and Challenges of FDI in Retail in India, IOSR Journal of Humanities and Social Science, 5(5), pp. $99-109$
Coe, N. M. and M. Hess (2005). The internationalization of retailing: implications for supply network restructuring in East Asia and Eastern Europe, Journal of Economic Geography, 5, pp. $449-473$

Department of Industrial Policy and Promotion (2010). Foreign Direct Investment (FDI) in Multi-brand Retail Trading. Discussion Paper.

Duran, C. (2007). Externalities from foreign direct investment in the Mexican retailing sector, Cambridge Journal of economics, 31, pp. $393-411$

Gupta, R. (2012). FDI in Indian Retail Sector: Analysis of Competition in Agri-Food Sector, Internship Project Report, Competition Commission of India.

Guruswamy, M., K. Sharma, J. P. Mohanty, and T. J. Korah. (2005). FDI in India's Retail Sector: More Bad than Good? Economic and Political Weekly, 40(7), pp. 619-623

Kalhan, A. (2007). Impact of Malls on Small Shops and Hawkers, Economic and Political Weekly, 42 (22), pp. 2063 $-2066$.

Mukherjee, A., D. Satija, T. M. Goyal, M. K. Mantrala, and S. Zou (2011). Impact of the Retail FDI Policy on Indian Consumers and the Way Forward, ICRIER Policy Series No. 5

Patibandla, M. (2012). Foreign Direct Investment in India's Retail Sector: Some Issues, Working Paper No. 366, Indian Institute of Management Bangalore.

Sarma, E. A. S. (2005). Need for Caution in Retail FDI, Economic and Political Weekly, 40(46), pp. $4795-4798$.

Technopak. (2012). Foreign Direct Investment (FDI) in Retail: An Objective Assessment of FDI's Impact on the Indian Retail Sector and the Indian Economy, White Paper. Gurgaon: Technopak Advisors Pvt. Ltd. Downloaded on March 29, 2013 from:

http://www.technopak.com/resources/retail/Technopak\% 20Whitepaper_FDI\%20in\%20Retail.pdf

The Boston Consulting Group (2012). The Tiger Roars: Capturing India's Explosive Growth in Consumer Spending. Downloaded on March 29, 2013 from:

https://www.bcgperspectives.com/Images/BCG_The_Tiger _Roars_Feb_12_tcm80-97584.pdf 